\title{
Feasibility of Introducing English as a Partial Medium of Instruction in Iranian Senior High Schools
}

292 Viabilidad de introducir el inglés como medio parcial de instrucción en las escuelas secundarias iraníes

Viabilidade de introduzir o inglês como meio parcial de ensino nas escolas secundárias iranianas

Mohammad Reza GHORBANI

University of Bojnord, Iran

ghorbani@ub.ac.ir

https://orcid.org/o000-0002-I233-399I

Received: 03/10/2019

Sent to peer review: 01/11/2019

Accepted by peers: 19/01/2020

Approved: $23 / 01 / 2020$

DOI: 10.5294/laclil.2019.12.2.5

To reference this article (APA) / Para citar este artículo (APA) / Para citar este artigo (APA) Ghorbani, M. R. (2019). Feasibility of adopting English as a partial medium of instruction for mathematics and science subjects in Iranian senior high school. Latin American Journal of Content \& Language Integrated Learning, 12(2), 292-320. https://doi.org/10.5294/ laclil.2019.12.2.5 
ABSTRACT. The use of Content and Language Integrated Learning has been increasing in many European countries simultaneous to the use of English as a medium of instruction in the non-Anglophone countries due to globalization and internationalization. Since the 1979 revolution, discussion on English as a medium of instruction in the Iranian formal education has been a taboo. This study aims to figure out the possibilities of introducing English as a partial medium of instruction (EPMI) for mathematics and science at senior high schools. The convergent mixed methods design was used to collect perspectives of students, content area teachers, parents, and administrative staff in Bojnord through e-mail interviews and survey questionnaires. The majority of the interviewees in the qualitative phase as well as most of the students, parents, teachers, and administrative staff in the quantitative phase have supported the possible use of EPMI. The findings of this study suggest future considerations to assist language education authorities in taking decisions to overcome students' language proficiency constraints while developing efficient and effective programs for CLIL.

Keywords (Source: Unesco Thesaurus): English as a partial medium of instruction; EMI; English as a foreign language context; content and language integrated learning; CLIL; secondary education; internationalization; globalization.

RESUMEN. El uso del Aprendizaje Integrado de Contenidos y Lenguas Extranjeras ha aumentado en muchos países europeos simultáneamente al uso del inglés como medio de instrucción en los países no angloparlantes como resultado de la globalización y la internacionalización. Desde la revolución de 1979, la discusión sobre el inglés como medio de instrucción en la educación formal iraní ha sido un tabú. Este estudio busca descubrir las posibilidades de introducir el inglés como un medio parcial de instrucción (EPMI) para las matemáticas y las ciencias en las escuelas secundarias superiores. El diseño de métodos mixtos convergentes se utilizó para recopilar las perspectivas de los estudiantes, los maestros del área de contenido, los padres y el personal administrativo en Bojnord a través de entrevistas por correo electrónico y cuestionarios de encuestas. La mayoría de los entrevistados en la fase cualitativa, así como la mayoría de los estudiantes, padres, maestros y personal administrativo en la fase cuantitativa han apoyado el posible uso de EPMI. Los resultados de este estudio sugieren consideraciones futuras para ayudar a las autoridades educativas del lenguaje a tomar decisiones para superar las limitaciones de dominio del idioma de los estudiantes mientras desarrollan programas eficientes y efectivos para AICLE.

Palabras clave (Fuente: tesauro de la Unesco): inglés como medio de instrucción parcial; aprendizaje integrado de contenidos y lenguas extranjeras; inglés como medio de instrucción; AICLE; inglés como lengua extranjera; contexto; enseñanza secundaria; internacionalización; globalización.

RESUMO. O uso da Aprendizagem Integrada de Conteúdo e Línguas aumentou em muitos países europeus simultaneamente com o uso do inglês como meio de instrução em países que não falam inglês, como resultado da globalização e da internacionalização. Desde a revolução de 1979, a discussão sobre o inglês como meio de instrução na educação formal iraniana tem sido um tabu. Este estudo procura descobrir as possibilidades de introduzir o inglês como meio parcial de instrução (EPMI) para matemática e ciências nas escolas de ensino médio. O projeto de métodos mistos convergentes foi usado para coletar as perspectivas de alunos, professores da área de conteúdo, pais e funcionários administrativos em Bojnord por meio de entrevistas por e-mail e questionários de pesquisa. A maioria dos entrevistados na fase qualitativa, bem como a maioria dos alunos, pais, professores e funcionários administrativos na fase quantitativa, apoiaram o possível uso do EPMI. Os resultados deste estudo sugerem considerações futuras para ajudar as autoridades de ensino de línguas a tomarem decisões para superar as limitações de proficiência linguística dos alunos enquanto desenvolvem programas eficientes e eficazes para o CLIL.

Palavras-chave (Fonte: tesauro da Unesco): inglês como meio de instrução parcial; aprendizagem integrada de conteúdo e línguas estrangeiras; inglês como meio de instrução; CLIL; inglês como língua estrangeira; contexto; ensino médio; internacionalização; globalização. 


\section{Introduction}

According to Foroozandeh and Forouzani (2015), the initially introduced English textbooks for Iranian schools were compiled by a group of American and Iranian material developers in 1938. However, the Islamic Revolution in 1979 led to some hostility towards the United States and the United Kingdom. As a result, English was considered as an alien language, and the Iranian political attitudes towards the English language were negative in the immediate aftermath of the revolution (Borjian, 2013). Sadeghi and Richards (2016) state that the prevailing negative attitude towards English became different a few years later when Imam Khomeini, the founder and supreme leader of the Islamic Revolution, emphasized the significance of learning foreign languages.

As pointed out by Zare-ee and Hejazi (2017), even families who are in a low socio-economic status with financial problems, do their best to send their children to private language institutes because they know that sound English proficiency will increase their opportunities of employment. However, English as a medium of instruction (EMI) is currently confined to Departments of English, irrespective of emphasis on Persian as the official language in Iran. Even the universities, which are allowed to admit international students, do not use EMI. That is, international students with a different language background have to learn Persian so that they can continue their studies in Iranian universities.

In Iran, English is taught and practiced as a foreign language in a contextually restricted environment. All public and private high schools nationwide have to use the prescribed English textbooks, which are centrally compiled, developed and published by the Ministry of Education (Ghorbani, 2009). Both teachers and learners have to focus only on formal grammatical features of English due to the washback effect of final and national tests. That is why many students are unable to use English communicatively after graduating from senior high schools (Ghorbani, 2009; Ghorbani \& Neissari, 2015).

According to Sadeghi and Richards (2016), the prevailing 5+3+4 education system was replaced by the $6+3+3$ education system in 2013 . According to the new system, primary school lasts for six years, without English as a subject in the curriculum. English is formally intro- 
duced as a required course in the first grade of junior high school and lasts for three years, and is continued to be taught at senior high school for another three years, for 2-4 hours a week.

In this study, English is suggested only as a partial medium of instruction in the overall curriculum, which will not cause students to deviate from using their first language. This reason also encourages the author to preferably use EPMI rather than EMI or Content and Language Integrated Learning (CLIL). To the author's knowledge, except for Ghorbani and Alavi (2014) and Zare-ee and Hejazi (2017), no research has been conducted in this regard. Therefore, this study aims at figuring out the potential possibilities of implementing EPMI for MSSs at Iranian Senior High Schools (SHSs). This concept, which is called "bilingual education," is further promoted through CLIL, considering it as an instructional design.

According to Met and Lorenz (1997) and Airey (2009), research has shown that limitations of our language ability may make expression and exploration of complex concepts so difficult for us. That is why EPMI is more positively justified than EMI in the Iranian EFL context. However, as pointed out by Otto (2018), due to the duality between content and language and lack of enough research findings, assessment has still become challenging under CLIL.

\section{Review of literature}

While the crucial role of the English language as a lingua franca has already been studied in detail (Jenkins, 2013; Seidlhofer, 2011), Dearden (2015) believes that EMI is a relatively new and evolving concept. EMI is different from CLIL, in which the language of education may not be English. CLIL is defined by Coyle, Hood, and Marsh (2010) as "a dual-focused educational approach in which an additional language is used for the learning and teaching of both content and language" (p. 1). However, in this study, CLIL refers to the methodology used to address pedagogic aspects of Mathematics and Science delivered in English in the current bilingual education curriculum in Iran. Since the focus of this study is dual (both content and language focusing on English) on the selected subjects delivered in English in the curriculum, the term EPMI is preferably used. 
Nonetheless, despite a number of cultural, political, economic, and implementational constraints, EMI has been increasingly introduced into the Non-Anglophone Countries (NACs) due to globalization (Brumfit, 2004; Chiti-Batelli, 2003; Gardt \& Hüppauf, 2004; Zare-ee \& Hejazi, 2017) and internationalization (Coleman, 2006; Vinke, Snippe, \& Jochems, 1998) of education. According to Soruç and Griffiths (2017), in spite of its negative consequences, "this global expansion is showing no signs of slowing down" (p. 1). The CLIL implemented in a developmental model has been well-understood as a suitable path for internationalization without subtractive bilingualism or semilingualism, which is mostly a result of EMI.

Local and native languages have conventionally been the medium of instruction in many countries for years. According to Zare-ee and Hejazi (2017), the application of EMI has recently attracted much attention and is rapidly growing due to globalization and internationalization; however, it is mostly an imposed practice in colonial counties. According to Dearden (2015), EMI refers to "the use of the English language to teach academic subjects in countries or jurisdictions where the first language (L1) of the majority of the population is not English" (p. 2). Rose and McKinley (2017) define it as "an educational system where content is taught through English in contexts where English is not used as the primary, first or official language" (p. 4).

Research shows that the most efficient language for primary school education is the children's first language, and other languages are more likely to make students drop out of school (UNESCO, 2008a). According to Benson and Kosonen (2013), mother-tongue based education is a successful way for streamlining marginalized children in schools. Research findings of the UNESCO (2008b) show a growing focus on promoting mother tongue-based education.

Since the 1979 revolution, discussion about EMI in the Iranian context has been a taboo. Based on Dearden's (2015) report, of of the 55 countries she studied, $70.9 \%$ of the public secondary schools and $87.3 \%$ private secondary schools reported that EMI was allowed. Iran is among the countries where EMI is not allowed, either in terms of public and private sectors or different levels in education (such as primary, secondary, and tertiary). Although her findings show that EMI is very likely to increase in some educational systems in future, its use in the 
contexts like Qatar has led to the parents' and teachers' displeasure (Ahmadi, 2017; Ellili-Cherif, 2014).

According to Ashcraft (2006), content area teachers (CATs) are affected by EMI because EMI demands extra knowledge and skills and puts an additional burden on teachers and learners who are less proficient in the selected foreign languages. Furthermore, Hellekjaer and Westergaard (2003) suggest that EMI in NACs constrains the teaching methods of CATs. According to Ahmadi (2017), 63.63\% of Qatari male students are displeased with the EMI reforms in their country. Furthermore, Ellili-Cherif (2014) argues that, although the adoption of EMI in Qatar is aimed at future success, it has led to teachers' displeasure and additional financial burden on parents.

Meanwhile, despite the effectiveness of the first language as a medium of instruction (Heugh, 2002), the use of CLIL has become a growing global trend and phenomenon (Chang, 2010; Coetzee, 2004; Coleman, 2006; Crystal, 2004; Dafouz \& Guerrini, 2009; Doiz, Lasagabaster, \& Sierra, 2013; Dearden, 2015; Dearden \& Macaro, 2016; Ghorbani \& Alavi, 2014; Graddol, 1997; Kirkgöz, 2005; Kurtán, 2004; Manakul, 2007; Wong, 2010; Zare-ee \& Hejazi, 2017). At the same time, the need for English as a second language (ESL) or English as a foreign language (EFL) in study courses is increasingly needed in educational settings (Coleman, 2006; Crawford-Camiciottoli, 2004; Evans \& Green, 2007; Fortanet \& Bellés, 2005), indicating the assistance of English as a dominant medium in CLIL.

In examining the effects of CLIL on students' motivation and perception of pedagogic aspects with regard to English in CLIL in an English preparatory school at a university in Istanbul, Mede and Cinar (2018) have found out a remarkable improvement. This was visible in their sense of responsibility, grammar performance, and vocabulary knowledge, too. At the same time, the majority of learners' and their teachers' perception about CLIL classes was positive.

According to Costa and Coleman (2013), the growth of English in the CLIL courses can be attributed to factors such as rapid scientific knowledge advancement, additional course content availability in English, academic staff and student mobility acceleration, and employment priority. As pointed out by Zhang (2017), the CLIL courses are primarily aimed at teaching content knowledge rather than improving English proficiency; however, they can increase learners' language proficiency and motivation for language learning (Yang, 2015). 
On the other hand, Phillipson (1992) sees possible dominance of English over other languages in CLIL as a significant threat to linguistic variety. Stavans and Hoffmann (2015) stress the antagonistic attitudes towards English in the CLIL courses especially in bilingual regions in which a minority language is actively used. Vu and Burns (2014) report that lecturers' and students' language proficiency, learning styles, pedagogical issues, and resources are the main emerging challenges for Vietnamese tertiary lecturers when English is applied. However, the global growth of multilingualism and technological advancements has led to new educational requirements in which people feel they need to know several languages (Van Der Worp, 2017).

Nonetheless, textbook and journal publication in English (Ashcraft, 2006; Mauranen, Hynninen, \& Ranta, 2010), competition in public and private sector education (Dearden, 2015), globalization (Brumfit, 2004; Chiti-Batelli, 2003; Gardt \& Hüppauf, 2004; Zare-ee \& Hejazi, 2017), academic internationalization (Coleman, 2006; Vinke, et al., 1998), international market competition (Ashcraft, 2006; Graddol, 2006), worldwide visa (Ratna, 2017) and students' EFL/ESL improvement (Chang, 2010; Khan, 2011; Wong, 2010; Wu, 2006) are mentioned in the literature as the rationale and apparent drives for rapid expansion of English through CLIL classes in NACs. However, further research is needed in this regard.

Chiti-Batelli (2003) considers that English as a lingua franca facilitates globalization largely. According to Soruç and Griffiths (2017), English looks like an inexorable lingua franca in the world. It is used for business, social interactions, travels, educational purposes, and entertainments. English is increasingly becoming the main language used for educational purposes. A study by Van Der Worp (2017) on 194 Business Administration students at the University of the Basque Country has revealed that CLIL classes increased students' confidence, especially in oral skills, to use English in their future workplace. Kym and Kym (2014) found that applying English in the CLIL classes was important for Korean students' current academic and future career success. A study by Berger (2011) in Japan has revealed that a large number of students preferred English as the only medium of instruction in class.

In their study at a private university in Istanbul, Turkey, Soruç and Griffiths (2017) tried to find the difficulties that students experience 
with English in their CLIL classes, and the strategies they use to deal with those problems. They identified 27 distinct difficulties with CLIL. The reasons of their difficulties were related to speaking and listening, the teacher and class, vocabulary, affection, and cognition. They also identified 36 strategies that students employed to cope with their difficulties. They concluded that teaching and learning in a foreign language is a challenging task that requires more research to ensure the best possible outcomes.

According to Tekin (2015), the Englishization associated with future success is a common trend at the administrative level in the Persian Gulf. For an example, the Omanis welcomed English in their CLIL classes with open arms. For the Kuwait government, English in CLIL classes means learning improvement (Alrabah, Wu, Alotaibi, \& Aldaihani, 2016). Saudi Arabia is establishing English in CLIL classes at different educational levels (Khan, 2011).

However, Iran does not seem to share a common belief with neighboring countries. A study conducted by Ghorbani and Alavi (2014) in this regard in the Iranian context reveals that, although teachers and students are in support of English in CLIL classes, it is absent in formal education. Also, Zare-ee and Hejazi (2017) reported that $80 \%$ of Iranian university teachers preferred to teach non-language subjects (e.g., Physics and Mathematics) in English. To date, only a few Sama Junior high schools, affiliated to the Islamic Azad University, have been allowed to partially and informally teach Mathematics and Science in English. To the author's knowledge, there is no sign of official governmental backing for English in the CLIL classes.

According to Murphy (2014), the EMI expansion is happening rapidly, not only in tertiary education, but also in secondary and primary education. Dearden (2015) surveyed 55 countries and reported that the increasing trend of adopting EMI could be observed in secondary education due to possible top-down pressure from tertiary education. The results of a study by Ghorbani and Alavi (2014) in the Iranian context suggested a longitudinal plan for implementing EMI. That is, EMI should be applied gradually at different levels of education. The implementation of EMI has led to both positive and negative reactions among CLIL students and teachers (Ratna, 2017). To modify this controversy, this study aimed at exploring stakeholders' perspectives on the potential application of the EPMI in Iranian SHSs. 


\section{Method}

The convergent, parallel, mixed methods research design was used to explore the perceptions of SHSs, CATs, Ps, and AS regarding the potential adoption of EPMI for MSSs at Iranian SHSs in this study. After collecting, analyzing, and interpreting the data separately, the researcher integrated the inferences.

\section{Objectives of the study}

1. To explore senior high school students' perceptions regarding the potential adoption of English as a partial medium of instruction for mathematics and science in Iranian senior high schools.

2. To explore content area teachers' perceptions regarding the potential adoption of English as a partial medium of instruction for mathematics and science in Iranian senior high schools.

3. To explore parents' perceptions regarding the potential adoption of English as a partial medium of instruction for mathematics and science in Iranian senior high schools.

4. To explore administrative staff's perceptions regarding the potential adoption of English as a partial medium of instruction for mathematics and science in Iranian senior high schools.

5. To compare the perceptions of senior high school students, content area teachers, parents, and administrative staff regarding the potential adoption of English as a partial medium of instruction for mathematics and science in Iranian senior high schools.

\section{Research questions}

Five general questions were asked from 12 purposively selected informants in Bojnord to gather qualitative data. The qualitative research questions are as follows:

1. What are the informants' perspectives regarding the potential introduction of EPMI for MSSs in SHSs?

2. To what extent is the educational infrastructure (such as qualified teachers, pedagogical guidelines, and educational resources) suitable to gradually begin the provision of EPMI in SHSs? 
3. What are the potential constraints and solutions to the EPMI provision for MSSs in SHSs?

4. What level (primary school, junior high school, or senior high school) of school is appropriate to gradually begin the provision of EPMI? Justify it.

5. What type (public or private) of school is appropriate to gradually begin the provision of EPMI? Justify it.

Furthermore, the following research question was developed to compare the SHSSs, CATs, Ps, and AS's perceptions based on their responses to the survey questionnaire items:

Is there any significant difference among the SHSSs, CATs, Ps, and AS's perceptions regarding the potential adoption of EPMI for MSSs at Iranian SHSs?

\section{Research hypothesis}

The following null hypothesis was formulated to answer the above-mentioned question:

There is no significant difference among the SHSSs, CATs, Ps, and AS's perceptions regarding the potential adoption of EPMI for MSSs in Iranian SHSs.

\section{Sample and data collection}

The mixed method was used to collect perspectives of SHSs, CATs, Ps, and AS in Bojnord (the capital of the North Khorasan province) through e-mail interviews and survey questionnaires. Twelve participants (see the demographic characteristics of the informants in Appendix D) were purposively selected for the interviews. As for the questionnaires, stratified random sampling was used to proportionately select a representative sample (see the descriptive statistics for the four Groups in Appendix D) from the accessible population in typical schools. To maintain each participant's privacy and confidentiality (Creswell, 2012), their pseudo initials were used to profile them. As recommended by Dearden and Macaro (2016), in order to further protect their anonymity, the details of their specialization fields were not identified. 
In this study, a typical school refers to a normal and average (public or private) school. The students' level of proficiency is assumed to be lower intermediate. All the students are from an under-privileged area based on a quota system used to select students through the national university entrance examination. The students' scores are calculated based on the three geographical regions, including privileged, under-privileged, and deprived areas. Bojnord, where the data was collected, is an under-privileged area; therefore, the findings may be generalizable to such areas.

E-mail interviews (see the interview protocol in Appendix B) and the paper-and-pencil, self-administered questionnaires (see the questionnaire in Appendix C and the cover letter in Appendix A) were used in this study. However, this self-administered approach was supposed to be ideal for this study because neither computer literacy nor access to the Internet was necessary. The questionnaires were manually distributed among respondents.

Based on the objectives of the study, review of the related literature, especially Dearden (2015), and modification of a previously developed questionnaire by Ghorbani and Alavi (2014), the author developed the interview questions and the survey questionnaire items. All of the questionnaire items, except for the demographic or personal questions, are measured on a six-point continuum Likert-type scale. Following the recommendations by Ary, Jacobs, Razavieh, and Sorensen, (2010), the favorable and positive items were coded as 1= Strongly Disagree, 2 = Disagree, 3 = Slightly Disagree, $4=$ Slightly Agree, 5 = Agree, and $6=$ Strongly Agree. In the cover letter of the survey, the participants were informed that their participation was voluntary and that filling out the survey indicated their consent.

Six experts reviewed and assessed the instruments to determine their content and face validity. For the field test, three SHSs, three CATs, three Ps, and three members of AS reviewed the items and helped the author to improve the overall instrument quality. For the pilot test, 38 SHSs, 35 CATs, 33 Ps, and 32 members of AS answered the items and helped the author to establish the reliability of the survey questionnaire. The overall reliability of the scores from the four groups was 0.84 . By deleting seven items $(5,8,15,20,25,28$, and 30$)$, which had a correlation of less than 0.3 , the value increased to 0.88 . 


\section{Data analysis}

Exploratory factor analysis (EFA) was used to establish the construct validity of the questionnaire by calculating the correlations among all the items and identifying factors through groups of highly correlated items. Based on the EFA results, 53.26\% of the total variance was explained by three factors. The first factor (infrastructure) was comprised of eight items $(1,2,3,4,6,7,9$, and 10) reported on a 6-point Likert scale that explained $17.37 \%$ of the variance. The second factor (culture) included eight items $(11,12,13,14,16,17,18$, and 19) reported on a 6-point Likert scale that explained $20.21 \%$ of the variance. In addition, the third factor (motivation) consisted of seven items (21, 22, 23, 24, 26, 27, and 29) reported on a 6 -point Likert scale that explained $15.66 \%$ of the variance.

The researcher followed the interrelated steps recommended by Creswell (2012) in qualitative and quantitative data analysis and interpretation. The computer software Statistical Package of Social Sciences (SPSS version 19) was used to calculate one-way between-groups Analysis of Variance (ANOVA). ANOVA was conducted to compare the possible differences between the means of the four groups (HSSs, CATs, Ps, and AS) to whom the questionnaires were administered.

\section{Results}

\section{Results of the quantitative data}

The descriptive statistics (N, Mean, and Standard deviation) for the four sets of scores are presented in Table 1.

Table 1. Descriptive statistics of scores for the four groups

\begin{tabular}{|c|c|c|c|}
\hline Groups & N & Mean & Standard deviation \\
\hline HSSs & 99 & 118.37 & 19.10 \\
\hline CATs & 47 & 110.63 & 17.62 \\
\hline Ps & 79 & 117.10 & 20.16 \\
\hline AS & 27 & 101.74 & 16.77 \\
\hline
\end{tabular}

Source: Own elaboration. 
As indicated in Table 2, there was a statistically significant difference among the four groups: $\mathrm{F}(3,248)=6.58, \mathrm{P}=.000$. Therefore, the research hypothesis fails in acceptance.

Table 2. One-Way Analysis of Variance of Scores for the four Groups

\begin{tabular}{|l|c|c|c|c|c|}
\hline \multicolumn{1}{|c|}{ Source } & df & SS & MS & F & p \\
\hline Between groups & 3 & 7100.85 & 2366.95 & 6.58 & .000 \\
\hline Within groups & 89088.39 & 248 & 359.22 & & \\
\hline Total & 96189.25 & 251 & & & \\
\hline
\end{tabular}

Source: Own elaboration.

Post-hoc comparisons using the Tukey HSD test indicated that the mean score for AS Group ( $M=101.74, S D=16.77)$ was significantly different from HSSs Group $(M=118.37, S D=19.10)$ and Ps Group $(M=$ 117.10, $S D=20.16)$. Based on these quantitative results, most of the HSSs, Ps, and CATs were for the application of EPMI, respectively, while the AS was hardly for it. This result implies that, since members of the AS are appointed by the government, they are probably affected by the political stance of the government. Figure 1 presents the results in a graphical form to add more clarity to them.

Figure 1. Scores of the four groups

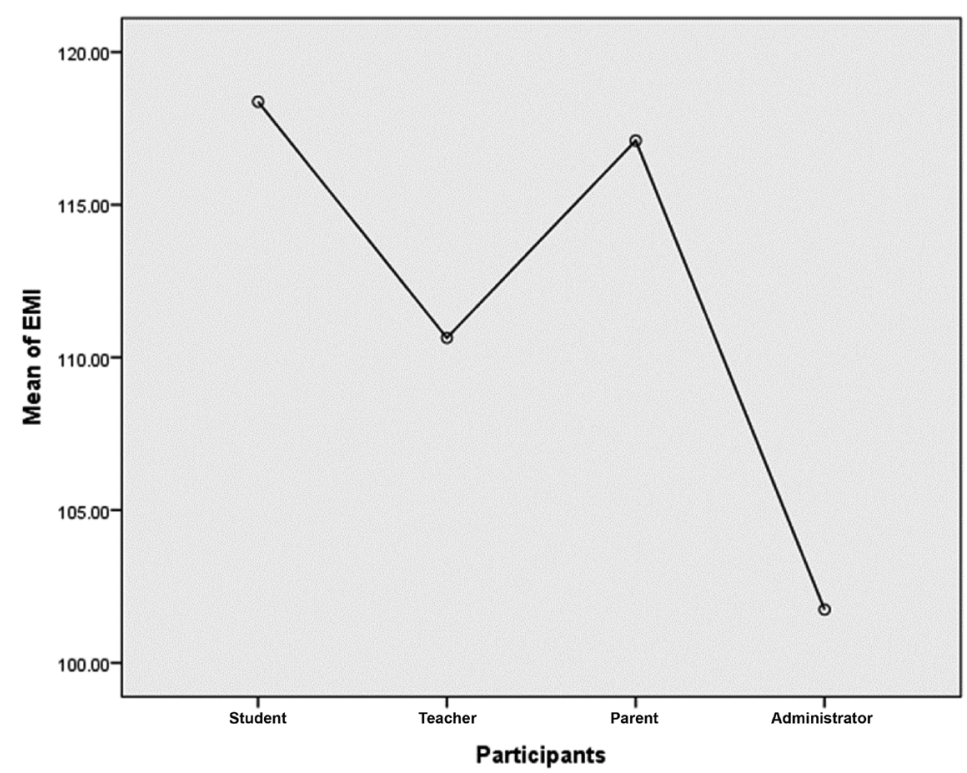

Source: Own elaboration. 


\section{Results of the qualitative data}

Generally speaking, the qualitative results indicated that participants valued EPMI over Persian as the only medium of instruction. The qualitative data analysis and interpretation revealed that, as a whole, the informants suggested EPMI especially for the private schools and at the primary school level. They believed that every initiative regarding EFL teaching should begin at elementary school because age is a key factor in language learning. Also, they unanimously emphasized that this should happen at private schools, which have more freedom, because public schools are not authorized by the Iranian constitution to use EMI. They enumerated different reasons both for and against feasibility of EPMI; however, their main concern was teachers' and students' low proficiency of English. The details are delineated in the related tables.

Table 3. indicates the descriptive data related to the interviewees' characteristics.

Table 3. Demographic characteristics of the informants

\begin{tabular}{|l|c|}
\hline \multicolumn{1}{|c|}{ Characteristics } & Percentage \\
\hline HSSs (one from each grade) & 25 \\
CATs (one from each field) & 33.3 \\
Ps (one from each grade) & 25 \\
AS (one male and one female) & 16.7 \\
Total & 100 \\
\hline Male & 50 \\
Female & 50 \\
Total & 100 \\
\hline
\end{tabular}

Source: Own elaboration.

Table 4 summarizes the informants' perspectives regarding potential introduction of EPMI for MSSs in SHSs.

Table 4. The potential introduction of EPMI

\begin{tabular}{|l|c|}
\hline \multicolumn{1}{|c|}{ Themes } & Percentage \\
\hline Positive: & 33.3 \\
\hline Generally speaking, it improves students' learning. & 16.7 \\
\hline It develops students' knowledge of vocabulary & 8.3 \\
\hline It makes students interested in English. & \\
\hline
\end{tabular}




\begin{tabular}{l|c|}
\hline \multicolumn{2}{|l|}{ Negative: } \\
\hline $\begin{array}{l}\text { It is not suitable because students are weak regarding their } \\
\text { knowledge of English. }\end{array}$ & 25 \\
\hline $\begin{array}{l}\text { It is not possible because there are not many knowledgeable } \\
\text { teachers. }\end{array}$ & 16.7 \\
\hline
\end{tabular}

Source: Own elaboration.

Eight interviewees (58.3\%) are for EPMI application because they believe that it is beneficial, and five (41.7\%) are against it because of students' and teachers' low proficiency. Table 5 indicates the informants' perspectives regarding educational infrastructure for the provision of EPMI in SHSs.

Table 5. The educational infrastructure for EPMI

\begin{tabular}{|l|c|}
\hline \multicolumn{1}{|c|}{ Themes } & Percentage \\
\hline Infrastructure is not a hindrance for this type of instruction. & 41.7 \\
Infrastructure is not enough. & 25 \\
EFL teachers are not proficient enough. & 25 \\
Students are not proficient enough. & 8.3 \\
\hline
\end{tabular}

Source: Own elaboration.

Five informants (41.7\%) believe that the present infrastructure is not a problem for EPMI application, while three of them (25\%) think that it is not sufficient. Others (33.3\%) refer to teachers' and students' low proficiency as an obstacle.

Table 6 shows the informants' perspectives regarding potential constraints and solutions to the EPMI provision for MSSs in SHSs.

Table 6. The potential constraints and solutions

\begin{tabular}{|l|c|}
\hline \multicolumn{1}{|c|}{ Themes } & Percentage \\
\hline Teachers' and students' low proficiency is the main constrain. & 58.3 \\
Employing proficient teachers is suggested as a solution. & 16.7 \\
EMl should begin at lower levels of education. & 8.3 \\
Teacher education should be emphasized. & 8.3 \\
Changing the negative attitude of students towards English is & 8.3 \\
necessary. & \\
\hline
\end{tabular}

Source: Own elaboration. 
As it is mentioned in Tables 4 and 5, teachers' and students' proficiency is the key factor. It is viewed both as the main constraint and as the solution. Seven participants (58.3\%) regard low proficiency as a constraint and two (16.7\%) suggest proficient teachers as the solution.

Table 7 delineates the informants' perspectives regarding the level of school appropriate to begin the provision of EPMI. Half of the participants $(50 \%)$ recommend elementary school, four (33.3\%) suggest junior high school, and two (16.7\%) put forward senior high school as the appropriate level for beginning the EPMI provision.

Table 7. The level of school appropriate to begin EPMI

\begin{tabular}{|l|c|}
\hline \multicolumn{1}{|c|}{ Themes } & Percentage \\
\hline Elementary school & 50 \\
Junior high school & 33.3 \\
Senior high school & 16.7 \\
\hline
\end{tabular}

Source: Own elaboration.

Table 8 indicates the informants' perspectives regarding the type of school appropriate to begin the provision of EPMI. Except for $8.3 \%$ of participants, others (91.7\%) suggest private schools for the EPMI provision because they know that foreign languages are not allowed by the Iranian constitution.

Table 8. The type of school appropriate to begin EPMI

\begin{tabular}{|l|c|}
\hline \multicolumn{1}{|c|}{ Themes } & Percentage \\
\hline Private schools & 91.7 \\
Both private and public schools & 8.3 \\
\hline
\end{tabular}

Source: Own elaboration.

\section{Discussion}

The findings of this study show that the majority of the interviewees $(58.3 \%)$ in the qualitative phase as well as the majority of the SHSs (65/76\%), Ps (65.05\%), and CATs (61/46\%) in the quantitative phase have supported the possible use of EPMI. However, only $56.52 \%$ of the 
AS has supported it, implying that, since they are appointed by the government, they are probably affected by the political stance of the government. These findings are in alignment with those of Van Der Worp (2017), Kym and Kym (2014), Berger (2011), Ghorbani and Alavi (2014), and Zare-ee and Hejazi (2017), respectively.

However, the findings do not coincide with those of Ahmadi's (2017) study, in which $63.63 \%$ of Qatari male students viewed the EMI reforms as a waste of time in their country. They were also not in alignment with Ellili-Cherif's (2014) findings that the adoption of EMI in Qatar had led to teachers' displeasure (78\%). As concluded by Soruç and Griffiths (2017), these contradicting results show that teaching and learning in a foreign language is a challenging task that requires further research to ensure possible outcomes at their optimum. One important reason the difference between the findings of this study and those of other researchers is that EPMI is different from EMI. Switching between the source language and the target language seems to reduce the problems associated with applying the strict form of EMI.

\section{Conclusion}

As emphasized by Zare-ee and Hejazi (2017), conducting research on EMI is important because communication and dissemination of knowledge in Persian is limited. Also, Iranian academics need to become members of international scientific communities and have access to cutting-edge research findings. Furthermore, an increase in the number of language institutes throughout the country implies that public opinion favors EMI. In this regard, Iranian policy-makers' and educationists' opinions may not be necessarily in agreement with the public on which some research is in order. Based on the results of this study, it is suggested that a number of implications be taken into account before initiating EPMI programs in the Iranian context.

First, prospective CATs should be specifically trained and screened for their language abilities. Second, CATs should be provided with pedagogical guidelines and effective teaching techniques that are suitable for their own contexts so that they can encourage their students' in- 
volvement and cope with teaching issues in the EPMI classroom. Third, up-to-date English materials on CLIL and adequate facilities should be accessible to motivate both teachers and students. Fourth, the adoption of EPMI may seem to be unlikely in the immediate future; however, private schools, having fewer political, cultural, economic, and implementational constraints, will probably begin to employ and portray EPMI as the distinctive characteristic of their education so that they can increase the number of their students.

The limitations of this study affect the scope of generalization from the findings which need to be treated with caution. The small number of participants from a provincial capital city may not be a good representative sample to reflect generalizable perspectives. Nonetheless, the findings of this study could potentially lead to an acrimonious debate among the Iranian EFL experts and language policy officials. They could also assist policy-makers to consider the issues raised here and develop efficient and effective EPMI programs. Furthermore, they could contribute to highlighting and illustrating some of the constraints (teacher training, material development, and students' language proficiency) of developing efficient and effective programs for CLIL courses that might be used in future research. Finally, it can be reasonably argued that it is highly unlikely for Iranian officials to push forward EPMI merely based on the findings of this study. Therefore, further research is necessary. They can extend this study in terms of different geographical regions (privileged, under-privileged, or deprived), educational levels (primary, secondary, or tertiary), educational types (private or public), and people's perspectives (teachers or students).

\section{References}

Ahmadi, Q. S. (2017). Unwelcome? English as a medium of instruction (EMI) in the Arabian Gulf. English Language Teaching, 10(8), 11-17. https://doi.org/10.5539/elt.v10n8p11

Airey, J. (2009). Estimating undergraduate bilingual scientific literacy in Sweden. International CLIL Research Journal, 1, 26-35. https://www.researchgate.net/publication/260311133_Estimating_bilingual_scientific_literacy_in_Sweden 
Alrabah, S., Wu, S., Alotaibi, A. M., \& Aldaihani, H. A. (2016). English teachers' use of learners' L1 (Arabic) in college classrooms in Kuwait. English Language Teaching, 9(1), 1-11. https://doi.org/10.5539/elt.v9n1p1

Ary, D., Jacobs, L. C., Razavieh, A., \& Sorensen, C. (2010). Introduction to research in education ( $8^{\text {th }} \mathrm{Ed}$.). Belmont, CA: Wadsworth Cengage Learning.

Ashcraft, N. (2006). The human impact of the conversion to English-medium instruction. Proceedings from College of Humanities \& Social Sciences: The Seventh Annual U.A.E University Research Conference. UAEU Funded Research Publications, 22, 11-16.

Benson, C., \& Kosonen, K. (Eds.). (2013). Language issues in comparative education: Inclusive teaching and learning in non-dominant languages and cultures. Rotterdam, the Netherlands: Sense Publishers.

Berger, M. (2011). English-only policy for all? Case of a university English class in Japan. Polyglossia, 3, 27-43. https://www.apu.ac.jp/rcaps/uploads/fckeditor/publications/polyglossia/Polyglossia_V20_Berger.pdf

Borjian, M. (2013). English in post-revolutionary Iran: From indigenization to internationalization. Clevedon, Avon: Multilingual Matters.

Brumfit, C. J. (2004). Language and higher education: Two current challenges. Arts and Humanities in Higher Education, 3(2), 163-173. https://doi. org/10.1177/1474022204042685

Chang, Y. (2010). English-medium instruction for subject courses in tertiary education: Reactions from Taiwanese undergraduate students. Taiwan International ESP Journal, 2(1), 55-84. https://nurulfarhani7971. weebly.com/uploads/2/7/5/4/27546657/emi_3.pdf

Chiti-Batelli, A. (2003). Can anything be done about the 'glottophagy' of English? A bibliographical survey with a political conclusion. Language Problems and Language Planning, 27(2), 137-153. https://doi. org/10.1075/lplp.27.2.03chi

Coetzee, W. (2004). Design principles for English medium course material for speakers of other languages (Unpublished doctoral dissertation). The Open University, UK.

Cohen, J. W. (1988). Statistical power analysis for the behavioral sciences $\left(2^{\text {nd }}\right.$ Ed.). Hillsdale, NJ: Lawrence Erlbaum Associates.

Coleman, J. A. (2006). English-medium teaching in European higher education. Language Teaching, 39(1), 1-14. https://doi.org/10.1017/ S026144480600320X 
Costa, F., \& Coleman, J. A. (2013). A survey of English-medium instruction in Italian higher education. International Journal of Bilingual Education and Bilingualism, 16(1), 3-19. https://doi.org/10.1080/13670050.2012.676621

Coyle D., Hood, P., \& Marsh, D. (2010). CLIL: Content and language integrated learning. Cambridge, UK: Cambridge University Press.

Crawford-Camiciottoli, B. (2004). Interactive discourse structuring in L2 guest lectures: Some insights from a comparative corpus-based study. Journal of English for Academic Purposes, 3(1), 39-54. http://doi. org/10.1016/S1475-1585(03)00044-4

Creswell, J. W. (2012). Educational research: Planning, conducting, and evaluating quantitative and qualitative research ( $4^{\text {th }}$ Ed.). New York, NY: Pearson.

Crystal, D. (2004). The past, present, and future of World English. In A. Gardt \& B. R. Hüppauf (Eds.), Globalization and the future of German (pp. 27-45). Berlin, Germany: Mouton de Gruyter.

Dafouz, E., \& Guerrini, M. C. (Eds.). (2009). CLIL across Educational Levels: Experiences from primary, secondary and tertiary contexts. Madrid, Spain: Santillana Educación/Richmond Publishing.

Dearden, J. (2015). English as a medium of instruction: A growing global phenomenon. Oxford, UK: British Council.

Dearden, J. \& Macaro, E. (2016). Higher education teachers' attitudes towards English medium instruction: A three-country comparison. Studies in Second Language Learning and Teaching, 6(3), 455-486. https:// files.eric.ed.gov/fulltext/EJ1134377.pdf

Doiz, A., Lasagabaster, D., \& Sierra, J. (2013). Globalisation, internationalisation, multilingualism and linguistic strains in higher education. Studies in Higher Education, 38(9), 1407-1421. https://doi.org/10.1080/ 03075079.2011 .642349

Ellili-Cherif, M. (2014). Integrated language and content instruction in Qatar independent schools: Teachers' perspectives. Teacher Development, 18(2), 211-228. https://doi.org/10.1080/13664530.2014.900819

Evans, S., \& Green, C. (2007). Why EAP is necessary: A survey of Hong Kong tertiary students. Journal of English for Academic Purposes, 6(1), 3-17. https://doi.org/10.1016/j.jeap.2006.11.005

Foroozandeh, E., \& Forouzani, M. (2015). Developing school English materials for the new Iranian educational system. In C. Kennedy (Ed.), English Language Teaching in the Islamic Republic of Iran: Innovations, Trends and Challenges, (pp. 59-72). London, UK: British Council. 
Fortanet, I., \& Bellés, B. F. (2005). Spoken academic discourse: An approach to research on lectures. Volumen Monográfico, 25, 161-178. https:// www.researchgate.net/publication/28128935_Spoken_academic_ discourse_An_approach_to_research_on_lectures

Gardt, A., \& Hüppauf, B-R. (Eds.) (2004). Globalization and the future of German. Berlin, Germany: Mouton de Gruyter.

Ghorbani, M. R. (2009). ELT in Iranian high schools in Iran, Malaysia and Japan: Reflections on how tests influence use of prescribed textbooks. The Journal of Reflections on English Language Teaching, 8,(2), 131-139. https://www.researchgate.net/publication/313073927_ELT_in_Iranian_high_schools_in_Iran_Malaysia_and_Japan_Reflections_on_ how_tests_influence_use_of_prescribed_textbooks

Ghorbani, M. R. \& Neissari, M. (2015). Washback effect of the Iranian concours on senior high school students' EFL learning activities. Iranian Journal of Language Testing, 5(1), 1-28. https://www.researchgate.net/ publication/318339723_Washback_effect_of_the_Iranian_concours_ on_senior_high_school_students'_EFL_learning_activities

Ghorbani, M. R., \& Alavi, S. Z. (2014). Feasibility of adopting English-medium instruction at Iranian universities. Current Issues in Education, 17(1), 1-18. https://cie.asu.edu/ojs/index.php/cieatasu/article/view/1277

Graddol, D. (1997). The future of English? A guide to forecasting the popularity of the English language in the 21st century. London, UK: The British Council.

Graddol, D. (2006). English next. British Council. Retrieved from https:// englishagenda.britishcouncil.org/sites/default/files/attachments/ books-english-next.pdf

Hellekjaer, G. O., \& Westergaard, M. R. (2003). An exploratory survey of content learning through English at Nordic universities. In C. Van Leeuwen \& R. Wilkinson (Eds.). Multilingual approaches in university education: Challenges and practices (pp. 65-80). Nijmegen, The Netherlands: ValkhofPers.

Heugh, K. (2002). The case against bilingual and multilingual education in South Africa: Laying bare the myths. Perspectives in Education, 20, 171-198. https://hdl.handle.net/10520/EJC87116

Jenkins, J. (2013). English as a lingua franca in the international university: The politics of academic English language policy. Abingdon, UK: Routledge.

Khan, I. A. (2011). The teacher of English: Pedagogic relevance in Saudi Arabia. English Language Teaching, 4(2), 112-120. https://doi.org/10.5539/ elt.v4n2p112 
Kirkgöz, Y. (2005). Motivation and student perception of studying in an English-medium university. Journal of Language and Linguistic Studies, 1(1), 101-122. https://www.jlls.org/index.php/jlls/article/view/10

Kurtán, Z. (2004). Foreign-language-medium instruction in Hungarian higher education. In R. Wilkinson (Ed.), Integrating content and language: Meeting the challenge of a multilingual higher education (pp. 126136). Masstricht, the Netherlands: Universitaire Pers Maastricht.

Kym, I., \& Kym, M. H. (2014). Students' perceptions of EMI in higher education in Korea. The Journal of Asia TEFL, 11(2), 35-61. http://www.asiatefl.org/main/download_pdf.php?i=49\&c=1404136303\&fn=11_2_02.pdf

Manakul, W. (2007). Role of English in internationalization of higher education: The case of the graduate school of engineering. Higher Education and Lifelong Learning, 15, 155-162. https://high.high.hokudai. ac.jp/wp-content/uploads/2016/02/No1513.pdf

Mauranen, A., Hynninen, N., \& Ranta, E. (2010). English as an academic lingua franca: The ELFA project. English for Specific Purposes, 29(3), 183-190. https://doi.org/10.1016/j.esp.2009.10.001

Mede, E. \& Cinar, S. (2018). Implementation of Content and Language Integrated Learning and its effects on student motivation. LACLIL, 11(2), 215-235. https://doi.org/10.5294/laclil.2018.11.2.3

Met, M., \& Lorenz, E. B. (1997). Lessons from U.S. immersion programs: Two decades of experience. In R. K. Johnson \& M. Swain (Eds.), Immersion education: International perspectives (pp. 243-264). Cambridge University Press, Cambridge, UK.

Murphy, V. (2014). Second language learning in the early school years: Trends and contexts. Oxford, UK: Oxford University Press.

Otto, A. (2018). Assessing language in CLIL: A review of the literature towards a functional model. LACLIL, 11(2), 308-325. https://doi. org/10.5294/lacli1.2018.11.2.6

Phillipson, R. (1992). Linguistic imperialism. Oxford, UK: Oxford University Press.

Ratna, A. S. (April, 2017). Controversy behind applying EMI (English as the Medium of Instruction) among EFL students. Proceedings of the Ninth International Conference on Applied Linguistics (CONAPLIN 9): Advances in Social Science, Education and Humanities Research (ASSEHR), 82, 58-63. https://doi.org/10.2991/conaplin-16.2017.12 
Rose, H., \& McKinley, J. (2017). Japan's English medium instruction initiatives and the globalization of higher education. https://ora.ox.ac.uk/objects/ uuid:8fefd80a-5afe-45f0-adb7-2344ea988dd3

Sadeghi, K., \& Richards, J. C. (2016). The idea of English in Iran: An example from Urmia. Journal of Multilingual and Multicultural Development, 37(4), 419-434. https://doi.org/10.1080/01434632.2015.1080714

Seidlhofer, B. (2011). Understanding English as a lingua franca. Oxford, UK: Oxford University Press.

Soruç, A., \& Griffiths, C. (2017). English as a medium of instruction: Students' strategies. ELT Journal, ccx017, 1-11. https://doi.org/10.1093/elt/ccx017

Stavans, A. \& Hoffmann, C. (2015). Multilingualism. Cambridge, UK: Cambridge University Press.

Tekin A. (2015). Early EFL education is on the rise in Oman: A qualitative inquiry of parental beliefs about early EFL learning. English Language Teaching, 8(2), 35-43. http://doi.org/10.5539/elt.v8n2p35

UNESCO. (2008a). Mother tongue matters: Local language as a key to effective learning. Paris, France: UNESCO.

UNESCO. (2008b). Mother tongue instruction in early childhood education: A selected bibliography. Paris, France: UNESCO.

Van Der Worp, K. (2017). English medium instruction: A way towards linguistically better prepared professionals in the Basque Autonomous Community? International Journal of Multilingualism, 14(1), 53-68. http://doi.org/10.1080/14790718.2017.1258994

Vinke, A. A., Snippe, J., \& Jochems, W. (1998). English-medium content courses in non-English higher education: a study of lecturer experiences and teaching behaviors. Teaching in Higher Education, 3, 383394. https://doi.org/10.1080/1356215980030307

Vu, N. T. T., \& Burns, A. (2014). English as a medium of instruction: Challenges for Vietnamese tertiary lecturers. The Journal of Asia TEFL, 11(3), 1-31. https://www.researchgate.net/publication/283083963_English_as_a_ medium_of_instruction_Challenges_for_Vietnamese_tertiary_lecturers

Wong, R. M. H. (2010). The effectiveness of using English as the sole medium of instruction in English classes: Student responses and improved English proficiency. Porta Linguarium 13, 119-130. https:// www.researchgate.net/publication/46014984_The_Effectiveness_ of_Using_English_as_the_Sole_Medium_of_Instruction_in_English_ Classes_Student_Responses_and_Improved_English_Proficiency 
Wu, W. S. (2006). Students' attitudes toward EMI: Using Chung Hua University as an example. Journal of Education and Foreign Language and Literature, 4, 67-84.

Yang, W. (2015). Content and language integrated learning next in Asia: Evidence of learners' achievement in CLIL education from a Taiwan tertiary degree programme. International Journal of Bilingual Education and Bilingualism, 18(4), 361-382. https://doi.org/10.1080/13670050.20 14.904840

Zare-ee, A., \& Hejazi, S. Y. (2017). University teachers' views on English as the medium of instruction in an Iranian higher education institution. Arab World English Journal (AWEJ), 8(4), 467-485. https://doi. org/10.24093/awej/vol8no4.32

Zhang, H. (2017). What makes an effective English-medium course in China? Experiences and perspectives of international undergraduates. RELC Journal, 1-16. https://doi.org/10.1177/0033688217691815 


\section{Appendix}

\section{Appendix A}

\section{Cover Letter}

Dear Participant,

The purpose of this research is to collect information concerning your perceptions on the possibilities of implementing English as a Partial Medium of Instruction (EPMI) for Mathematics and Science Subjects (MSSs) in Iranian Senior High Schools (SHSs). Your participation in this study is voluntary. Your anonymity is assured. That is, you will not be individually identified with your responses.

Simply do not fill out the survey if you do not consent. Your willingness to return the completed survey questionnaire/interview form indicates your consent to participate in this study. The usefulness of this questionnaire/interview form depends entirely on your honesty, candor, and care with which you respond to each of the items. All information you provide will be treated with confidentiality.

Finally, I would like to offer my sincere thanks to your participation and contribution to this study. If you have any questions about this study, please do not hesitate to contact me at mrg872@gmail.com.

Thank you in advance for your great help.

\section{Appendix B}

\section{Interview Protocol}

Project: Feasibility of Adopting English as a Partial Medium of Instruction (EPMI) for Mathematics and Science Subjects (MSSs) in Iranian Senior High Schools (SHSs)

Interviewer: Mohammad Reza Ghorbani

Interviewee initials: 
Section one: Personal information

Position of the participant: Student $\square$ Teacher $\square$ Parent $\square$ Administrative staff $\square$

Gender: Male $\square$ Female $\square$

Grade (If a student): $10^{\text {th }} \square 11^{\text {th }} \square 12^{\text {th }} \square$

Teaching field (If a teacher): Mathematics $\square$ Biology $\square$ Chemistry $\square$ Physics $\square$

Teaching experience (If a teacher):

under 8 years $\square$ Between 8 \& 15 years $\square$ Between 15 \& 22 years $\square$ over 22 years $\square$

School type: Public $\square$ Private $\square$ Other $\square$

Highest academic qualification (Except for students):

Under diploma $\square$ Diploma $\square$ Bachelor $\square$ Master's $\square$ PhD $\square$

Your level of spoken English:

Elementary $\square$ Lower Intermediate $\square$ Intermediate $\square$ Upper intermediate $\square$ Advanced $\square$

Section 2: Participants' perceptions on the potential implementation of EPMI for MSSs in SHSs

What is your perspective regarding the potential introduction of EPMI for MSSs in SHSs?

To what extent is the educational infrastructure (like qualified teachers, pedagogical guidelines, and educational resources) suitable to gradually begin the provision of EPMI in SHSs?

What are the potential constraints and solutions to the EPMI provision for MSSs in SHSs?

What level (primary school, junior high school, or senior high school) of school is appropriate to gradually begin the provision of EPMI? Justify it.

What type (public or private) of school is appropriate to gradually begin the provision of EPMI? Justify it. 


\section{Appendix C}

\section{Survey Questionnaire}

Project: Feasibility of Adopting English as a Partial Medium of Instruction (EPMI) for Mathematics and Science Subjects (MSSs) in Iranian Senior High Schools (SHSs)

Researcher: Mohammad Reza Ghorbani

Section one: Personal information

Position of the participant: Student $\square$ Teacher $\square$ Parent $\square$ Administrative staff $\square$

Gender: Male $\square$ Female $\square$

Grade (If a student): $10^{\text {th }} \square 11^{\text {th }} \square 12^{\text {th }} \square$

Teaching field (If a teacher): Mathematics $\square$ Biology $\square$ Chemistry $\square$ Physics $\square$

Teaching experience (If a teacher):

under 8 years $\square$ Between 8 \& 15 years $\square$ Between 15 \& 22 years $\square$ over 22 years $\square$

School type: Public $\square$ Private $\square$ Other $\square$

Highest academic qualification (Except for students):

Under diploma $\square$ Diploma $\square$ Bachelor $\square$ Master's $\square$ PhD $\square$

Your level of spoken English:

Elementary $\square$ Lower Intermediate $\square$ Intermediate $\square$ Upper intermediate $\square$ Advanced $\square$

Section 2: Your perceptions on the potential implementation of EPMI for MSSs in SHSs

Tick ONE box for each of the items below to give your opinion.

Despite a shortage of educational infrastructure, it is possible to gradually begin the provision of EPMI.

6. Strongly Agree $\square$ 5. Agree $\square$ 4. Slightly Agree $\square$

3. Slightly Disagree $\square$ 2. Disagree $\square$ 1. Strongly Disagree $\square$

Despite a shortage of linguistically qualified teachers, it is possible to gradually begin the provision of EPMI. 
6. Strongly Agree $\square$ 5. Agree $\square$ 4. Slightly Agree $\square$

3. Slightly Disagree $\square$ 2. Disagree $\square$ 1. Strongly Disagree $\square$

Despite a lack of clear pedagogical guidelines for teaching, it is possible to gradually begin the provision of EPMI.

6. Strongly Agree $\square$ 5. Agree $\square$ 4. Slightly Agree $\square$

3. Slightly Disagree $\square$ 2. Disagree $\square$ 1. Strongly Disagree $\square$

Despite a lack of resources, it is possible to gradually begin the provision of EPMI.

6. Strongly Agree $\square$ 5. Agree $\square$ 4. Slightly Agree $\square$

3. Slightly Disagree $\square$ 2. Disagree $\square$ 1. Strongly Disagree $\square$

Without in-service teacher preparation programmes, it is impossi-

ble to begin the provision of EPMI.*

6. Strongly Agree $\square$ 5. Agree $\square$ 4. Slightly Agree $\square$

3. Slightly Disagree $\square$ 2. Disagree $\square$ 1. Strongly Disagree $\square$

Despite a number of cultural constraints, it is possible to gradually begin the provision of EPMI.

6. Strongly Agree $\square$ 5. Agree $\square$ 4. Slightly Agree $\square$

3. Slightly Disagree $\square$ 2. Disagree $\square$ 1. Strongly Disagree $\square$

Despite a number of political constraints, it is possible to gradually begin the provision of EPMI.

6. Strongly Agree $\square$ 5. Agree $\square$ 4. Slightly Agree $\square$

3. Slightly Disagree $\square$ 2. Disagree $\square$ 1. Strongly Disagree $\square$

Despite a number of economic constraints, it is possible to gradually begin the provision of EPMI.

6. Strongly Agree $\square$ 5. Agree $\square$ 4. Slightly Agree $\square$

3. Slightly Disagree $\square$ 2. Disagree $\square$ 1. Strongly Disagree $\square$

Despite a number of implementational constraints, it is possible to gradually begin the provision of EPMI.

6. Strongly Agree $\square$ 5. Agree $\square$ 4. Slightly Agree $\square$

3. Slightly Disagree $\square$ 2. Disagree $\square$ 1. Strongly Disagree $\square$

Without removing the related constraints, it is impossible to begin the provision of EPMI.*

6. Strongly Agree $\square$ 5. Agree $\square$ 4. Slightly Agree $\square$

3. Slightly Disagree $\square$ 2. Disagree $\square$ 1. Strongly Disagree $\square$

The introduction of EPMI will help students to learn about the culture of the target language. 
The introduction of EPMI will let students get on well with people in English speaking countries.

The introduction of EPMI will let students become involved in learning internationally.

The introduction of EPMI will let students make English speaking friends.

The introduction of EPMI will discourage the coinage of Persian words.*

The introduction of EPMI will help students to surf the net in English.

The introduction of EPMI will help students to perform better in international Olympiads.

The introduction of EPMI will help students to become internationally educated.

The introduction of EPMI will help students to get an internationally well-paid job.

The introduction of EPMI will probably result in cultural corruption.*

The introduction of EPMI will have a positive effect on the teaching and learning of MSSs.

The introduction of EPMI will increase the level of students' English language proficiency.

The introduction of EPMI will help students to use English materials and resources.

The introduction of EPMI will increase students' social prestige.

The introduction of EPMI will have an adverse effect on students' academic achievement.*

The introduction of EPMI will contribute to students' cognitive development.

The introduction of EPMI will give students personal satisfaction.

The introduction of EPMI will help students to understand complex concepts.

The introduction of EPMI will increase students' motivation.

The introduction of EPMI will be detrimental to students' mother tongue.* 